Review Article

\title{
Sustainable Land-based Aquaculture: Rational Utilization of Water, Land and
}

\section{Feed Resources}

\author{
Y. Avnimelech ${ }^{1}$, M.C.J. Verdegem ${ }^{2}$, M. Kurup ${ }^{3}$ and P. Keshavanath ${ }^{4}$
}

${ }^{1}$ Dept. of Civil \& Environmental Engineering, Technion, Israel Institute of Technology, Iseael, ${ }^{2}$ Aquaculture and Fisheries Group, Department of Animal Sciences, Wageningen University, the Netherlands, ${ }^{3}$ School of Industrial Fisheries, Cochin University of Science and Technology, Cochin, India

\section{Introduction}

Much has been said on the need to practice aquaculture in a sustainable manner, preferably without jeopardizing the environment (Naylor, et al. 2000 and FAO 1997). As a result, best management practices for the aquaculture industry, considering environmental, economic and social sustainability, have been established (e.g. www.gaalliance.org/bap.html). Standards of some organizations for organic farming restrict stocking density and maximum pond biomass per unit surface area. For example, to produce organic shrimps, less than 15 postlarvae (PL) per square meter should be stocked with shrimp biomass always remaining below $800 \mathrm{~kg} / \mathrm{ha}$ (e.g. Naturland standards 2004; www.naturland.de/ englisch/n2/NL-Stand-Aquaculture_01-2005. pdf). These rules were mainly put forward to protect shrimp health and welfare, and to avoid the development of diseases. Naylor et al. (2000) stated that "intensification implies increasing the density of individuals, which requires greater use and management of inputs and greater generation of waste products". Such rules or statements suggest that intensification will always lead to the production of more wastes or to a reduction of animal welfare, which should be avoided.

This places aquaculture developers into a dilemma, as there is also a need for the aquaculture industry to keep up with a growing demand for fish, due both to population growth and to the need to better feed the population with healthy food (Wijkstorm, 2003). Global capture fisheries reached its limits with $75 \%$ of the major fisheries being over-fished or fished at their biological limits (CEOS, 2005). Thus, the aquaculture industry carries the responsibility of increased fish supply. A five-fold increase in global aquaculture production is needed within the next five decades to maintain current aquatic food consumption levels (FAO, 2004).

\section{Correspondence:}

Y. Avnimelech

Dept. of Civil \& Environmental Engineering, Technion, Israel Institute of Technology, Haifa, 32000 Israel

Tel: $+972-3-7522406$

Fax: +972 -3- 6131669, E-mail: agyoram@techunix.technion.ac.il 
To achieve this, using conventional extensive aquaculture ponds, a five folds increase of water consumed and land occupied will be needed. Soil and water resources are scarce, and in many situations expanding pond area is no longer a viable option.

In this review, the hypothesis is put forward that intensification of pond aquaculture is possible, without discharging more wastes, and in accordance with established codes of conduct and best management practice standards. This can be done by applying low cost technologies, technologies that can be adopted by developing countries. Intensification of pond aquaculture is necessary to provide aquatic food consumption for future generations, without putting larger claims on our dwindling land and water resources and is thus a central feature of sustainable aquaculture.

\section{Increasing aquaculture production: needs and constraints:}

Presently, the total annual capture fisheries production, including marine and inland waters, is about 90 million metric tones. Total capture fisheries production has not grown since the mid 80 's and is not expected to do so in the future. About $30 \%$ of global capture fisheries production is not used as human food, but to produce fish meal and fish oil used in animal feeds.

The stagnating capture fisheries production is confronted with a growing demand for fish due to population growth and to an increase in the per capita fish consumption (Wijkstrom, 2003). In 2003, the per capita fish supply was 16.3 $\mathrm{kg} /$ caput, including China, and $13.3 \mathrm{~kg} /$ caput excluding China (FAO, 2004). The FAO would like to see a $53-200 \%$ increase in per capita consumption, to $25 \mathrm{~kg}$ in 2025 (New, 1991) and to $30-40 \mathrm{~kg}$ in 2050 (Wijkstrom, 2003). The growing gap between global fish demand and supply through capture fisheries is expected to be closed through aquaculture. Past and predicted aquaculture productions are given in Table (1).
Table 1: Global aquaculture production of finfishes, crustaceans and molluscs (FAOSTAT statistic database, www.fao.org. New 1991; Wijkstrom 2003).

\begin{tabular}{|c|c|c|c|c|c|c|}
\hline Year & 1953 & 1963 & 1973 & 1983 & 1993 & 2003 \\
\hline $\begin{array}{l}\text { Million } \\
\text { MT }\end{array}$ & 0.96 & 1.76 & 3.07 & 6.21 & 17.77 & 41.90 \\
\hline \multicolumn{7}{|c|}{ Expected (or required) production } \\
\hline Year & & 2010 & $2025^{(1)}$ & $2025^{(2)}$ & & 2050 \\
\hline Million MT & & 61 & 120 & 150 & & 210 \\
\hline Source & & $\begin{array}{l}\text { ijkstrom } \\
2003\end{array}$ & $\begin{array}{l}\text { New } \\
1991\end{array}$ & $\begin{array}{l}\text { New } \\
1991\end{array}$ & & $\begin{array}{l}\text { Wijkstrom } \\
2003\end{array}$ \\
\hline $\begin{array}{l}\text { Assun } \\
\text { one (i }\end{array}$ & 191 & r capita & nsump & ption iden & ntical & 1 to presen \\
\hline 2. Assum & ning re & mmen & ed FAO & 's $25 \mathrm{~kg} \mathrm{p}$ & per ca & capita. \\
\hline
\end{tabular}

Aquaculture production increased more than 40 times during the last 50 years and is expected to rise another 5 times in the coming 50 years. Such rise of aquaculture production has to be planned, considering the goal is to minimize environmental impact while optimizing resource utilization.

\section{Sustainable aquaculture: rational use of natural resources:}

Land based aquaculture operations use land and water, mostly fresh, but also brackish or marine water. On a global scale, fresh water resources are becoming scarce and expensive. About $41 \%$ of the world's population today lives in waterstressed river basins. In 2050, $70 \%$ of the world population will face water shortage (CEOS, 2005).

Water losses in pond-based aquaculture are mainly caused by evaporation and seepage. Drainage water can be transferred to a potentially new user, and therefore was not considered as a net loss (Although, drainage water is not reused in many cases, due to low quality and marginal accessibility). Daily evaporation is usually in the range of $2-10 \mathrm{~mm}$, i.e. $20-100 \mathrm{~m}^{3} /$ ha, depending on seasonal temperature and humidity (Yoo and Boyd, 1994; Boyd and 
Gross, 2000). Seepage from properly built ponds (i.e. not built on highly permeable soil) will be less than five mm per day (Yoo and Boyd, 1994). Combined evaporation and seepage losses can be considered to be around $10 \mathrm{~mm}$ per day, or about $3500 \mathrm{~mm}$ per year. In consequence, a 1-ha pond will use $35,000 \mathrm{~m}^{3}$ of water per year to replace evaporation and seepage losses.

Aquaculture lands must be more or less flat, easily drained and close to reliable water sources like rivers, lakes or artesian wells. Such lands are also in high demand for other purposes: urbanization, agriculture, wetland (including mangrove) conservation, recreation and tourism. Marine aquaculture farms do not use large quantities of fresh water, but are developed in the coastal zone where land is scarce: $60 \%$ of the world population lives within $60 \mathrm{~km}$ of the sea coast and more than two thirds of cities with over 2.5 million habitants are situated in the coastal zone (e.g. www.unesco.org/mab/apasco/project. htm). Coastal zones are ecologically sensitive, containing mangroves, coral reefs. and other unique ecosystems. The need to protect these environments leads to public and legal objections to any further enlargement of pond areas in coastal regions. For instance in India, where population density in the coastal zone is high, the Indian Supreme Court decided in 1996 not to allow construction of ponds within $500 \mathrm{~m}$ from the high tide line (www.fao.org/figis/servlet/ static?dom= legalframework\&xml= nalo_india. $\mathrm{xml})$. Other countries also limit construction of coastal ponds by demanding compliance with stringent environmental conditions. Getting permission to develop new aquaculture sites is becoming a difficult, time-consuming process all over the world.

\section{Intensity of production and use of resources:}

An overview of aquaculture systems, ranked by culture intensity from essentially enhancedfishing impoundments to super-intensive recirculating systems, is given in Table (2). The most extensive aquaculture systems are based on the stocking of fish in water impoundments and feeding the ponds with additional feeds such as grains, house and farm-yard residues. Annual yields are usually below $1000 \mathrm{~kg} / \mathrm{ha}$, though occasionally, yields of up to $2000 \mathrm{~kg} /$ ha are obtained. When better, more complete diets are used, yields of $2000-4000 \mathrm{~kg} / \mathrm{ha} / \mathrm{yr}$ are obtained. On a global scale, most ponds produce appreciably less than $4000 \mathrm{~kg} / \mathrm{ha} / \mathrm{yr}$. For instance, the average productivity of fish farms in India (1999-2000) was 2226kg/ha/yr- (Indian ministry of Agriculture).

Water use in aquaculture per $\mathrm{kg}$ fish produced decreases with the increase in production intensity. In an average extensive pond, with a yearly evaporation and seepage loss of $35,000 \mathrm{~m}^{3}$ /ha and an annual production of $2000 \mathrm{~kg} / \mathrm{ha}, 17.5$ $\mathrm{m}^{3}$ water is used to produce $1 \mathrm{~kg}$ of fish. Only $50 \%$ of this is needed when the production level doubles to $4000 \mathrm{~kg} / \mathrm{ha} / \mathrm{yr}$.

Table 2: Schematic presentation of pond intensity levels, approximate annual fish yields and limiting factors.

\begin{tabular}{|c|c|c|c|}
\hline Pond type & Intervention & Approximate yields $\left(\mathrm{kg} \mathrm{ha}^{-1} \mathrm{yr}^{-1}\right)$ & Limiting factors \\
\hline Minimal feed & $\begin{array}{l}\text { Minimal feeding with grains, } \\
\text { farm and home residues }\end{array}$ & $<2000$ & $\begin{array}{l}\text { Limits of primary production, } \\
\text { food chain efficiency }\end{array}$ \\
\hline Fed ponds & $\begin{array}{l}\text { Feeding by complete diet } \\
\text { pellets }\end{array}$ & $2000-4000$ & Early morning oxygen \\
\hline Night time aeration & $\begin{array}{l}\text { Night time or emergency } \\
\text { aerators, } \sim 1-5 \mathrm{hp} \mathrm{ha}^{-1}\end{array}$ & $4000-10,000$ & $\begin{array}{l}\text { Sludge accumulation, } \\
\text { anaerobic pond bottom }\end{array}$ \\
\hline $\begin{array}{l}\text { Intensive mixed } \\
\text { aerated ponds }\end{array}$ & $\begin{array}{c}24 \mathrm{hr} \text { aeration }>20 \mathrm{hp} \mathrm{ha} \\
{ }^{1}-150 \mathrm{hp} \mathrm{ha}^{-1}, \text { (pure oxygen) } \\
\text { Completely mixed }\end{array}$ & $20,000-100,000$ & Water quality control \\
\hline
\end{tabular}


Aquaculture production should increase fivefold in the next five decades. If such a production increase would be realized maintaining an average pond production of $2000 \mathrm{~kg} / \mathrm{ha} / \mathrm{yr}$, an additional $330 \mathrm{~m}^{3}$ fresh water/caput will be consumed, assuming an average annual per capita fish consumption of $35 \mathrm{~kg}$. This is more than three times the present residential per capita water consumption in developed countries and is similar to the total renewable per capita water resources in many Middle Eastern and North African countries (Rosegrant, et al. 2002). The real increase in water consumption will be much higher, as population growth still needs to be considered. In consequence, increasing fish production in extensive ponds cannot be sustainable, considering global water availability. Large-scale expansion of extensive pond aquaculture is also not possible due to land constraints. Assuming an annual production of $2000 \mathrm{~kg} / \mathrm{ha}, 5 \mathrm{~m}^{2}$ are needed to produce $1 \mathrm{~kg} / \mathrm{fish}$. To raise per capita fish supply by $\pm 20 \mathrm{~kg} /$ capita this means an additional $100 \mathrm{~m}^{2}$ per capita is needed, area which is simply not available. In consequence, increased aquaculture production will have to come primarily from increased intensity rather than from added area and more water consumption. The challenge is to raise productivity while maintaining environmental sustainability.

To minimize waste discharge, while putting a minimal claim on land and water resources, highly intensive pond systems were developed in various countries, such as the USA, the Netherlands, Germany and Israel. The total production from these systems is still less than $1 \%$ of global pond production. Highly intensive ponds rely heavily on continuous mixing and aeration. The production in highly intensive ponds is within the range of $10-200 \mathrm{~kg} / \mathrm{fish} / \mathrm{m} / \mathrm{yr}^{-}$, i.e. 50 to 1000 times higher per unit of water or land compared to extensive systems. However, these systems are expensive to operate and need reliable infrastructure, including emergency backup systems and supplies. Such systems are not likely to be used to produce low-cost fish, especially not in the developing countries, where more than $90 \%$ of aquaculture fish production and consumption takes place (FAO, 2004). An approach that is becoming very popular in recent years is the use bio floc technology (BFT). Water exchange in such ponds is limited or even null, leading to the accumulation of organic residues and to the development of a dense heterotrophic microbial population (Avnimelech, 2003 and McIntosh, 2001). As in all intensive aquaculture systems, inorganic nitrogen, including toxic ammonia and nitrite, accumulate in the water. This problem is prevented in ASP systems through the addition of carbonaceous substrates leading to assimilation and incorporation of the soluble inorganic nitrogen into microbial protein (Chamberlain, et al. 2001 and Tacon, et al. 2002). The microbial protein, aggregated in microbial flocs serves as a rich source of amino acids and growth factors for fish and shrimp, leading to significant recycling of protein and higher utilization of feed (Avnimelech, et al. 1994; Chamberlain, et al. 2001 and Tacon, et al. 2002).

Although with BFT systems depend on a massive input of energy for aeration and mixing, there are means to significantly raise pond productivity using similar principles, yet with low and medium cost technologies. The development, demonstration and dissemination of such technologies should be of high priority if the goal is to continue feeding a growing world population relying on truly sustainable aquaculture.

\section{Optimizing productivity in stagnant ponds:}

\section{Oxygen-depleted sediments versus an oxvgen- rich water column}

Highly intensive ponds are continuously and thoroughly mixed and aerated, keeping particulate matter suspended in an oxygenrich water column. The dominance of aerobic conditions is a pre-requisite to the operation such active suspension ponds. To make better use of existing extensive ponds (Further referred to as stagnant ponds), similar conditions favoring microbial development and nutrient cycling should be created. 
Nevertheless, the situation in stagnant ponds is different from bio floc technology ponds. In stagnant ponds, organic residues including uneaten feed, fecal pellets and dead algae settle to the pond bottom, creating a site of high biological oxygen demand. The oxygen supply to the pond bottom is limited, even in periods of natural mixing and surface re-aeration due to strong winds. In consequence, pond bottoms are oxygen-limited environments and often anaerobic (Avnimelech and Ritvo, 2003 and Meijer and Avnimelech, 1999). The water directly above the bottom is low in oxygen, also during day-time when the surface water is well oxygenated. Low oxygen availability affects benthic communities diversity and structure (Gray, et al. 2002 and Buzzelli, et al. 2002), including shrimp populations. Dissolved oxygen concentrations measured from $10-140 \mathrm{~cm}$ above the pond bottom in two different shrimp ponds, are shown in Fig. (1). At 11.00a.m., 7-8mg/L of oxygen was present close to the surface, as compared with $2-3 \mathrm{mg} / \mathrm{O}_{2} / \mathrm{L}$ at $10 \mathrm{~cm}$ above the bottom. The oxygen concentration gradually increased from the pond bottom toward the surface.

\section{Carbohydrate addition:}

Pond bottoms become more oxygen depleted when high quantities of organic matter are added to the pond. Thus, there is reason to expect that addition of carbonaceous substrates to enhance microbial activity will worsen the oxygen deficit and will not be effective in stagnant ponds.

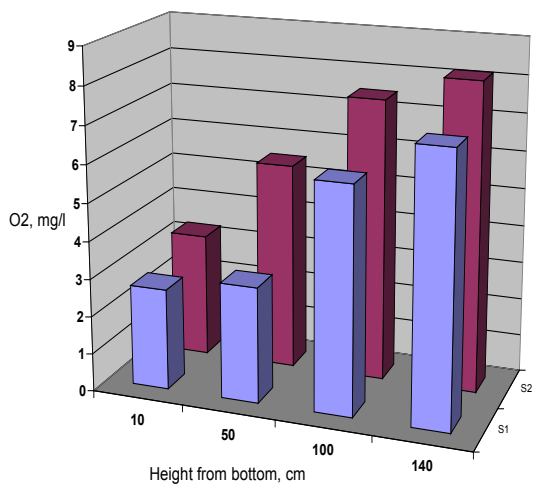

Fig. 1: Oxygen Profile In A Commercial Shrimp Pond, 11 am (Avnimelech and Serna, unpublished).
Studies by Hari, et al. demonstrated that the latter is not necessarily true. Microbial development and protein recycling was enhanced when supplementing a $25 \%$ protein feed with tapioca as carbohydrate source at a rate of $20 \mathrm{~g}$ tapioca for every $1 \mathrm{~g}$ of expected $\mathrm{NH}_{4}$ excretion, assuming that $50 \%$ of the dietary nitrogen is excreted. The effect of carbohydrate addition to stagnant ponds was similar to the results obtained in bio floc technology ponds (Table 3). A careful preparation of the pond bottom, removing accumulated organic matter prior to stocking through drying and scraping was practiced prior to stocking. A dense aerobic microbial community harvested by the shrimp developed on the oxidized pond bottom and enhanced production.

Though this work has to be repeated and expanded, it can be considered as a breakthrough and an indication of the feasibility of enhancing microbial processes to raise yields while lowering dietary protein levels and hence feeding costs. It has to be noted that shrimp yields were raised by $50 \%$, protein utilization doubled and net profit increased by a factor of five (Table 3).

Table 3: Summary of shrimp production in stagnant earthen ponds (Hari et al. 2004), as affected by feed $\mathrm{C} / \mathrm{N}$ ratio.

Control ponds, P40 got feed pellets with $40 \%$ protein. Treated ponds, $\mathrm{P} 25+\mathrm{CH}$, got $25 \%$ protein pellets + tapioca flour, at levels adjusted to induce full recycling of $\mathrm{N}$ excreted by shrimp.

\begin{tabular}{lcc}
\hline & P25 + CH & P 40 \\
\hline FCR & 1.6 & 2.2 \\
$\begin{array}{l}\text { N Retention, } \\
\text { \% (a) }\end{array}$ & 45 & 20 \\
Net yield, g/m ${ }^{2}$ & 64 & 45 \\
$\begin{array}{l}\text { Gross Return } \\
\text { (Rs/ha) }\end{array}$ & 193,275 & 125,406 \\
$\begin{array}{l}\text { Production costs } \\
\text { (Rs/ha) }\end{array}$ & 83,202 & 103,420 \\
$\begin{array}{l}\text { Net Profit } \\
\text { (Rs/ha) }\end{array}$ & 110,073 & 21,986 \\
\hline
\end{tabular}

Nitrogen accumulation in shrimp as a percentage of nitrogen added with feed. 


\section{Vertical substrate addition}

Another means to enhance microbial activity under aerobic conditions is to stimulate organic carbon accumulation on substrates in the water column, rather than on the pond bottom. Microbial communities containing algae, blue-green algae, bacteria, protists, zooplankton, and fungi embedded in an extracellular polysaccharide matrix develop on submerged surfaces. Within these communities, autotrophic or heterotrophic biomass dominates, depending on light, dissolved oxygen, and nutrient availability. The assemblage of attached organisms on submerged surfaces, including associated non-attached fauna is referred to as periphyton (Van Dam, et al. 2002). Placing either natural or synthetic submerged substrates (e.g. bamboo poles, plastic sheets etc.) in ponds leads to the adsorption of suspended organic matter on the vertical surfaces, at least partially replacing sedimentation and accumulation of organic matter at the pond bottom. Compared to organic matter at the bottom, the organic matter attached to substrates is exposed to oxygen rich water (e.g. Fig. 1) and is aerobically decomposed, thus contributing to a beneficial microbial food web. The microbial community developing on substrates can be manipulated using $\mathrm{C} / \mathrm{N}$ control in a way equivalent to the bio-floc technology system. Extensive work was conducted and published during the last decade on periphyton's role and ecology in aquaculture ponds (Azim, et al. 2005).

Providing substrate at a density of $1 \mathrm{~m}^{2} / \mathrm{m}$ of pond area increased the production of rohu (Labeo rohita) by $80 \%$ in fertilized ponds (Azim, et al. 2001a). Wahab et al. (1999) obtained a similar production increase with kalbaush ( $L$. calbasu) using a substrate density of $0.5 \mathrm{~m}^{2} / \mathrm{m}$ pond area. Not all fish species are able to utilize periphyton. For instance, gonia (L. gonius) in ponds with a substrate density of $1 \mathrm{~m}^{2} / \mathrm{m}$ of pond area did not yield a higher production compared to substrate free ponds (Azim, et al. 2001a). Proper selection of species for use in periphyton based aquaculture is important.
Substrate density influences production but the effect varies between species. With mahseer (Tor khudree) a substrate density of 98, 5-7 diameter, poles $25 / \mathrm{m}$ tank increased production $41 \%$ compared to pole-free tanks. Doubling the pole density to 196 poles $25 / \mathrm{m}$ led to a production increase of $51 \%$ (Keshavanath, et al. 2004). With tilapia (Oreochromis mossambicus $\times$ O. niloticus) using similar densities of poles, the production increased $112 \%$ at the low substrate density and $116 \%$ at the high substrate density (Keshavanath, et al. 2004). In addition, the fish production increase due to feeding a quality pellet-feed with species like masher and tilapia was less than when providing substrate for periphyton development (Keshavanath, et al. 2002, 2004). In consequence, providing substrate for periphyton developments in stagnant ponds contributed more to fish production than adding formulated feed.

The relation between periphyton and water quality was explored by Azim et al. (2003) using factorial analysis. Biofilm dislodgment increased with biofilm biomass. Attached algal development also positively influenced oxygen availability and decomposition in biofilms. In turn, nutrients released through decomposition stimulate autotrophic production by suspended and attached organisms. There is always competition between periphyton and phytoplankton for nutrients, but provided there is no nutrient limitation, the combined primary production by suspended and attached algae in periphyton-based systems is higher than in substrate-free ponds.

\section{Fish driven production enhancement:}

Besides the provision of substrate and feed to increase production, synergism was observed with specific species combinations stocked in polyculture ponds (Hepher, et al. 1989). In nonfed fertilized periphyton-based ponds, various mixed stocking ratios of rohu (L. rohita) and catla (Catla catla) yielded 50-210\% higher production than either species stocked in monoculture (Azim, et al. 2001b). By stocking 
a bottom feeder, e.g. calbaush, as a third species, the production was further enhanced, resulting in an annual production of $6,900 \mathrm{~kg} / \mathrm{ha} / \mathrm{yr}$ (Azim, et al. 2002).

Stocking of fish species that browse in the sediment for food may help to oxidize the pond bottom. This method is used traditionally by farmers worldwide. A recent experiment by Ritvo et al. (2004) demonstrated that stocking carps leads to an appreciable mixing of the sediment. Sulfide concentration, an indicator for anaerobic metabolism and a highly toxic species, was diminished to practically zero when carps were present at a density of about 1 fish/m (Fig. 2). The mixing of the sediment by fish resuspends organic particles into the aerobic water column and thus raises the fraction of aerobically metabolized organic matter. The combination of fish driven resuspension with submerged substrates may be even more efficient, due to the possibility that the resuspended organic particles will be trapped by the biofilms growing on submerged surfaces.

\section{Aeration:}

It has to be noted that an additional intensification can be achieved by the deployment of aerators, wherever possible. It was found, empirically, that even with a limited paddle wheel capacity of $2.5 \mathrm{hp} / \mathrm{ha}$, the oxygen stratification in the water column disappeared (Avnimelech, unpublished). In cases where there is an affordable, reliable and continuous energy supply, artificial aeration can be used to further raise the pond production capacity.

\section{Raising feeding efficiency:}

Modern aquaculture is based on the production of fish fed with artificial feeds. In most cases the feed contains a significant percentage of fish meal and fish oil to supply essential amino and fatty acids. Today, close to 30 million MT of fish caught annually through capture fisheries are used for fish meal and fish oil production (Barlow and Pike, 2001). This leads to an annual supply of 6 to 7 million MT of fishmeal and 1.1 to 1.4 million MT of fish oil. Of these amounts, 34 and $56 \%$, respectively, were used in aquaculture feeds in 2002, and this percentage is expected to increase to 48 and $79 \%$, respectively, by 2010 (Pike and Barlow, 2003).

Fishmeal is still the primary source of dietary protein in fish feeds (Olvera-Novoa, et al. 2002), mainly for carnivorous species with inclusion levels of $30-45 \%$. About $5 \mathrm{~kg}$ of wild fish are needed to produce $1 \mathrm{~kg}$ carnivorous fish, and an average of $1.9 \mathrm{~kg}$ wild fish is needed to produce $1 \mathrm{~kg}$ fish in ponds (Naylor, et al. 2000). Over-

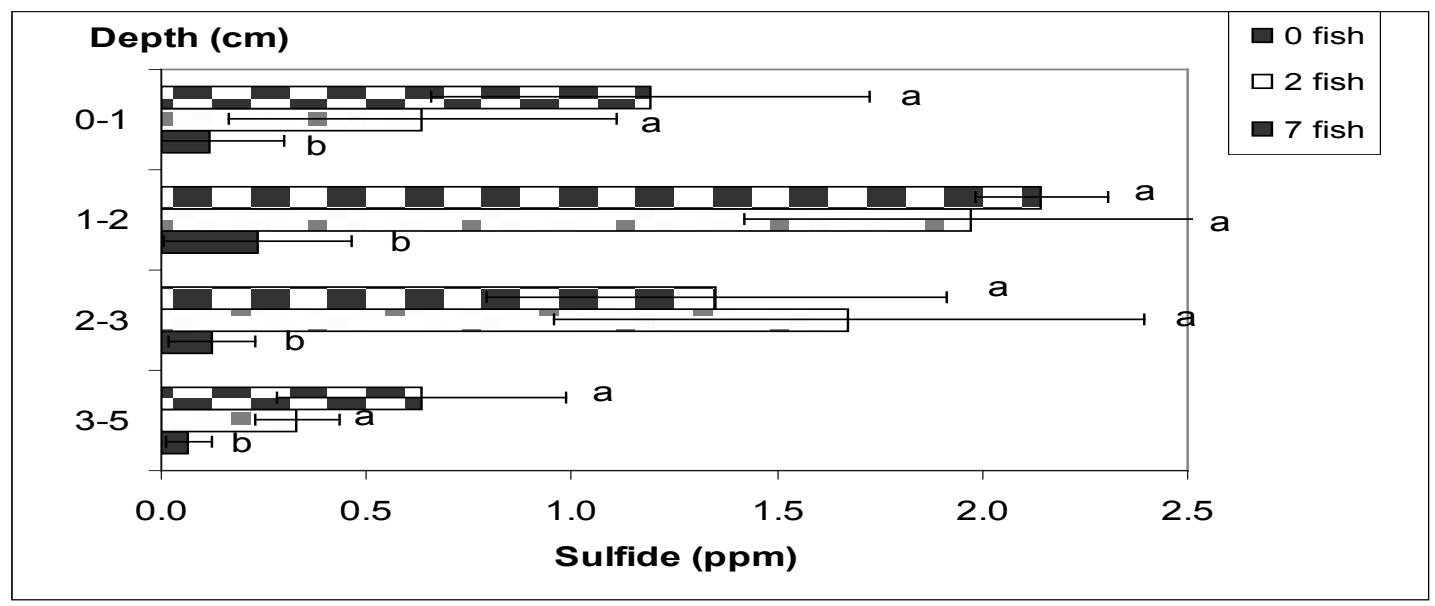

Fig. 2: Concentrations of total sulfide in pond bottom soil in enclosures $\left(6 \mathrm{~m}^{-2}\right) 45$ days subsequent to stocking by carp. Treatments with different letter are statistically differ at $\mathrm{P}$-value $<0.05$. Comparisons are within each soil depth slice. Error bars represent standard deviations. 
fishing in the ocean to obtain enough fishmeal and fish oil may endanger the global marine environment (Pauly, et al. 2002). On a longterm basis, relying on fishmeal and fish oil for aquaculture feed is not sustainable. One option to reduce the dependence of the aquaculture industry on fishmeal and fish oil is to maximize utilization of the natural food chain in the pond while maximizing feed utilization. A similar approach can also be applied to nutrients supplied through inorganic and organic fertilizers.

In bio floc technology, minimizing water exchange (Zero or very limited exchange), in combination with continuous aerating and mixing, leads to the development of a dense microbial population, metabolizing organic residues. Ammonium, nitrite, and nitrate concentrations in such systems are controlled through the addition of carbonaceous substrates ( $\mathrm{C} / \mathrm{N}$ control) to enhance microbial production (Avnimelech, 1999). Microbial proved to be an effective source of proteins, vitamins, and essential fatty acids for shrimp and several fish species (Decamp, et al. 2003, Tacon, et al. 2002). It was shown that proteins can be recycled through the activity of aerobic microorganisms and that protein utilization is doubled in BFT ponds (Avnimelech, et al. 1994 and McIntosh, 2000). Studies by Hari et al. demonstrated the same principles can be applied in stagnant ponds. The challenge is to further fine-tune this technology.

\section{Conclusions}

Fish, shellfish and crustaceans, collectively referred to as 'fish' in the text above, are essential sources of protein and healthy nutrition in large parts of the world. Capture fisheries cannot expand further (FAO, 2004). To increase the contribution of aquatic foods to human nutrition for a growing world population, aquaculture production should increase five-fold during the next five decades. Increasing aquaculture production by expanding the present pond area and raising water consumption is simply not possible. The necessary additional water use per capita would surpass more than three times today's residential water consumption in developed countries as well as the total per capita renewable water resources in many parts of the world. There is also not enough land available to further expand pond area. In consequence, the only sustainable way to increase aquaculture production is to intensify aquaculture, which today is mainly produced in extensive or fed ponds.

Stimulating microbial development in BFT ponds improved nutrient efficiency, and reduced the need for dietary fishmeal and fish oil, which in the long-term cannot be produced in sufficient quantities in a sustainable way. In addition, less nutrients were discharged while water use was minimized. Microbial activity is controlled through $\mathrm{C} / \mathrm{N}$ ratio manipulation, and the addition of carbonaceous substrates, leading to the doubling of protein utilization and supply of essential lipids and vitamins. The same principles can be applied to stagnant ponds by combining $\mathrm{C} / \mathrm{N}$ ratio control, with enhancement of periphyton development on submerged substrates and a reduction of organic matter accumulation in sediments through the stocking of bottom feeders. Previous studies showed that each of these techniques enhanced production in stagnant ponds, and further production increases might be obtained through synergism between the various techniques. Exploring such synergisms might lead to achieving a new blue revolution in aquatic systems, similar to the green revolution in terrestrial systems 40-50 year ago. The evidence brought in this paper demonstrates the importance and feasibility of raising ponds productivity and calls for a global effort to optimize, integrate and disseminate the appropriate technologies.

\section{References}

Avnimelech, Y. \& Ritvo, G. 2003. Shrimp and fish pond soils: Processes and management. Aquaculture, 220 (14): 549-567. 
Avnimelech, Y., Kochva, M. \& Diab, S. 1994. Development of controlled intensive aquaculture systems with a limited water exchange and adjusted carbon to nitrogen ratio. Israeli Journal of Aquaculture/Bamidgeh, 46 (3): 119-131.

Avnimelech, Y. 1999. Carbon nitrogen ratio as a control element in aquaculture systems. Aquaculture, 176 (3-4): 227-235.

Avnimelech, Y. 2003. Control of microbial activity in aquaculture systems: Active suspension ponds. World Aquaculture, 34 (4): 19-21.

Azim, M.E., Verdegem, M.C.J., van Dam, A.A. \& Beveridge, M.C.M. 2005. Periphyton: Ecology, exploitation and management, Wallingford, UK: CABI Publishing.

Azim, M.E., Milstein, A., Wahab, M.A. \& Verdegam, M.C.J. 2003. Periphyton-water quality relationships in fertilized fish ponds with artificial substrates. Aquaculture, 228 (14): 169-187.

Azim, M.E., Verdegem, M.C.J., Rahman, M.M., Wahab, M.A., van Dam, A.A. \& Beveridge, M.C.M. 2002. Evaluation of polyculture of Indian major carps in periphyton-based ponds. Aquaculture, 213 (14): 131-149.

Azim, M.E., Wahab, M.A., van Dam, A.A., Beveridge, M.C.M. \& Verdegem, M.C.J. 2001. The potential of periphyton-based culture of two Indian major carps, Rohu Labeo rohita (Hamilton) and gonia Labeo gonius (Linnaeus). Aquaculture Research, 32 (3): 209-216.

Azim, M.E., Wahab, M.A., van Dam, A.A., Beveridge, M.C.M., Huisman, E.A. \& Verdegem, M.C.J. 2001. Optimization of stocking ratios of two Indian major carps, rohu (Labeo rohita Ham.) and catla (Catla catla Ham.) in a periphyton-based aquaculture system. Aquaculture, 203 (12): 33-49.

Barlow, S.M. \& Pike, I.H. 2001. Aquaculture feed ingredients in year 2010: Fish meal and fish oil, Aquavision 98. $2^{\text {nd }}$ Nutreco Aquaculture Business Conference, eds. C.E. Nash \& V. Julien, Stavanger, Norway : 71.
Buzzelli, C.P., Luettich, R.A., Powers, S.P., Peterson, C.H., McNinch, J.E., Pinckney, J.L. \& Paerl, H.W. 2002. Estimating the spatial extent of bottom-water hypoxia and habitat degradation in a shallow estuary. Marine Ecology. Progress Series, 230: 103-112.

Boyd, C.E. \& Gross, A. 2000. Water use and conservation for inland aquaculture ponds, International Symposium on Water for Sustainable Inland Fisheries and Aquaculture. 23-26 Jun 1998, eds. R. Mueller \& H. Naeve, Blackwell Science, Oxford; United Kingdom: 55.

CEOS 2005, Earth observation handbook, http://www. eohandbook.com

Chamberlain, G., Avnimelech, Y., McIntosh, R.P. \& Velasco, M. 2001. Advantages of aerated microbial reuse systems with balanced C:N.II: Composition and nutritional value of organic detritus, The Global Aquaculture Advocate, 11: 22-24.

Decamp, O., Cody, J., Conquest, L., Delanoy, G. \& Tacon, A.G.J. 2003. Effects of salinity on natural community and production of Litopenaeus vannamei (Boone), within experimental zero-water exchange culture systems. Aquaculture Research, 34 (4): 345-355.

FAO 1997. Aquaculture development . FAO Technical Guidelines for responsible fisheries, FAO, Rome.

FAO 2004. The state of world fisheries and aquaculture, Food-and-Agriculture-Organization-of-the-United-Nations, Rome, Italy.

Gray, J.S., Wu, R.S. \& Ying, Y.O. 2002. Effects of hypoxia and organic enrichment on the coastal marine environment», Marine Ecology. Progress Series, 238: 249-279.

Hari, B., Kurup, B.M., Varghese, J.T., Schrama, J.W. \& Verdegem, M.C.J. 2004. Effects of carbohydrate addition on production in extensive shrimp culture systems. Aquaculture, $241(1 / 4):$ 179-194. 
Hari, B., Kurup, B.M., Varghese, J.T., Schrama, J.W. \& Verdegem, M.C.J. 2006. The effect of carbohydrate addition on water quality and the nitrogen budget in extensive shrimp culture systems. Aquaculture, 252 (2/4): 248-263.

Hepher, B., Milstein, A., Leventer, H. \& Teltsch, B. 1989. The effect of fish density and species combination on growth and utilization of natural food in ponds. Aquaculture and Fisheries Management (UK), 20 (1): 59-71.

Keshavanath, P., Gangadhar, B., Ramesh, T.J., van Dam, A.A., Beveridge, M.C.M. \& Verdegem, M.C.J. 2002. The effect of periphyton and supplemental feeding on the production of the indigenous carps Tor khudree and Labeo fimbriatus. Aquaculture, 213 (14): 207-218.

Keshavanath, P., Gangadhar, B., Ramesh, T.J., van Dam, A.A., Beveridge, M.C.M. \& Verdegem, M.C.J. 2004. Effects of bamboo substrate and supplemental feeding on growth and production of hybrid red tilapia fingerlings (Oreochromis mossambicus $\mathrm{x}$ Oreochromis niloticus). Aquaculture, 235 (14): 303-314.

McIntosh, P.R. 2001. Changing paradigms in shrimp farming. V. Establishment of heterotrophic bacterial communfities. Global Aquaculture Advocate, 4: 53-58.

McIntosh, P.R. 2000. Changing paradigms in shrimp farming. IV. Low protein feeds and feeding strategies. Global Aquaculture Advocate, 3: 44-50.

Meijer, L.E. \& Avnimelech, Y. 1999. On the use of microelectrodes in fish pond sediments. Aquacultural Engineering, 21 (2): 71-83.

Naturland 2004. Naturland Standards for Organic Aquaculture, Naturland-Association for Organic Agricultur, Registered Association, Germany.

Naylor, R.L., Goldburg, R.J., Primavera, J.H., Kautsky, N., Beveridge, M.C.M., Clay, J., Folke, C., Lubchenco, J., Mooney, H. \& Troell, M. 2000. Effect of aquaculture on world fish supplies. Nature, 405 (6790): 1017-1024.

New, M.B. 1991. Turn of the millennium aquaculture: Navigating troubled waters or riding the crest of the wave? The Annual Meeting of the World Aquaculture Society, Puerto Rico.
Olvera Novoa, M.A., Martinez Palacios, C.A. \& Olivera Castillo, L. 2002. Utilization of torula yeast (Candida utilis) as a protein source in diets for tilapia (Oreochromis mossambicus Peters) fry. Aquaculture Nutrition, 8 (4): 257 264.

Pauly, D., Christensen, V., Guenette, S., Pitcher, T.J., Sumaila, U.R., Walters, C.J., Watson, R. \& Zeller, D. 2002. Towards sustainability in world fisheries. Nature, 418 : 689-695.

Pike, I.H. \& Barlow, S.M. 2003. Impact of fish farming on fish stocks. Fish Farmer, 26 (1): 14-16.

Ritvo, G., Kochba, M. \& Avnimelech, Y. 2004. The effects of common carp bioturbation on fish pond bottom soil. Aquaculture, 242 (1/4): 345-356.

Rosegrant, M.W., Cal, X.M. \& Cline, S.A. 2002. World water and food to 2025: Dealing with scarcity, International Food Policy Research Institute., Washington, USA.

Tacon, A.G.J., Cody, J.J., Conquest, L.D., Divakaran, S., Forster, I.P. \& Decamp, O.E. 2002. Effect of culture system on the nutrition and growth performance of Pacific white shrimp Litopenaeus vannamei (Boone) fed different diets. Aquaculture Nutrition, 8 (2): 121-137.

Van Dam, A.A., Beveridge, M.C.M., Azim, M.E. \& Verdegem, M.C.J. 2002. The potential of fish production based on periphyton. Reviews in Fish Biology and Fisheries, 12 (1): 1-31.

Wahab, M.A., Azim, M.E., Ali, M.H., Beveridge, M.C.M. \& Khan, S. 1999. The potential of periphyton-based culture of the native major carp calbaush, Labeo calbasu (Hamilton). Aquaculture Research, 30 (6): 409-419.

Wijkstrom, U.N. 2003. Short and long-term prospects for consumption of fish. Veterinary Research Communications, 27 (Suppl.1): 461-468.

Yoo, K.H. \& Boyd, C.E. 1994. Hydrology and water supply for pond aquaculture, Van Nostrand Reinhold, New York; USA. 